\title{
Criminal interrogation and the right to remain silent - a study of the Hong Kong Customs service
}

\author{
Jessica Wing Kay Chiu \\ Department of Sociology, Hong Kong University, Room 1208, 12/F, K. K. Leung Building, \\ Pokfulam Road, Hong Kong. Tel: (852) 2859-2299; Fax (852) 2857-4074; email: \\ kaychiu@hkusua.hku.hk \\ Received 13 March 2008; accepted 22 May 2008 \\ Keywords: right to silence, Hong Kong, police interrogations, police \\ interviews, crime investigation, video interview system, rights of persons in \\ custody
}

results of this study of 150 Customs officers suggests that there might be benefits in rewording the Caution. Furthermore, statistical tests show that professional training and recruitment of front-line officers with higher academic qualifications would safeguard the administration of justice.

\section{INTRODUCTION}

The right to remain silent is an important issue for the legal justice system. However, very sparse research has been conducted in Hong Kong on the topic from the law enforcers' perspective, due in part to the difficulty of access to data subjects and the complexity of the issue. This lack of empirical research is not unique to Hong Kong. Leo (1996) also commented on the relatively small amount of empirical research in the United States into the actual practice of criminal interrogation as compared with doctrinal and ethical principles.

As a colony of Britain from 1842 to 1997, Hong Kong inherited the common law system, which affords the right of silence to individuals facing criminal proceedings. In 1997, sovereignty was returned
International Journal of Police Science and Management, Vol. 11 No. 2, 2009, pp. 217-235 DOI: $10.1350 /$ ijps.2009.11.2.127 
to China, where the right to silence is only gradually gaining recognition. In the same year, the Bill of Rights Ordinance, Cap 383 ('the Bill') codified the entitlement of a person not to testify against himself or herself. Hong Kong is therefore now at a crossroads in the development of a Caution that more fully reflects the legal principles in force and by which the right of the individual to fair trial is ensured.

The crucial question is whether there is a difference between actual practice as compared with the principles of the right to silence, since the effectiveness of the law is only as good as its enforcement. Customs officers are responsible for criminal law enforcement at the entry and exit points of Hong Kong as an adjunct to law enforcement provision by regular police within the territory. The administration of the right to silence by Customs reflects Hong Kong's determination to uphold the rule of law and abide by international standards of law enforcement.

The right to silence is communicated to the arrested person through a Caution prior to interrogation and the person is asked if he or she understands it. Furthermore, situational factors which have an influence on the process, including techniques of questioning, the psychological and physical conditions surrounding the inquiry process and whether the person was induced to admit, was threatened, or was placed under duress, need to be addressed in the administration of interrogation.

In the light of these legal, sociological and political developments, the objective of this study was to investigate Customs law enforcers' concept, understanding and implementation of the rules and directions governing collection of verbal evidence given by a suspect in custody. The extent of knowledge that Customs law enforcers possess in relation to the rights of persons in custody was examined. An understanding of the mental processes, concepts and decision criteria applied by Customs law enforcers in formulating questions and administering the interview, using statistical data analysis, is invaluable to future improvements and directions in training and recruitment. Officers' perceptions of the right to silence as it pertained to the Caution were also analysed.

The task has been made even more complex by the nature of the laws being enforced. On one hand, the element of a guilty conscience (mens rea) to the commission of an offence remains a crucial consideration during the judicial process. On the other hand, safeguarding the suspect against self-incrimination and protecting the individual's right to remain silent is essential to upholding the principles under the common law and the Bill. Furthermore, the existence of statutory exceptions for specific offences has the effect of reversing the right to remain silent.

Customs law enforcers therefore have a difficult task of understanding and implementing interrogation procedures for a wide range of offences. A majority of the Ordinances they enforce can be found under Schedule 2 of the Customs and Excise Service Ordinance, Cap 342. Officers are also explicitly required to enforce various other Ordinances, and authorised to enforce laws falling under the ambit of specified organisations as a form of agency duty, through the delegation of powers from the originating organisations.

In the face of a bilingual judicial system and the utilisation of a video interviewing system, the skills required of a Customs law enforcer have been multiplied. Their attitudes, opinions, knowledge of procedures, legal requirements and administrative constraints are essential to promulgating the use of technology, ensuring a consistent standard of questioning and the removal of hidden barriers. 


\section{BACKGROUND TO THE STUDY}

\section{Historical roots of the right to silence}

In his overview of the historical roots of the right to silence, Berger (1995) suggested that it originated from the West during the seventeenth and eighteenth centuries to protect religious and political freedom. $\mathrm{He}$ states that this principle was gradually extended to suspects and defendants in criminal cases. Underlying the right was that it would be unfair for the lone individual to have to stand up in contest against the resources of the State. The right is an important part of the presumption of innocence. It has more to do with fairness of administration of justice than the acquisition of truth.

Proponents of the abolition of the right claim that other methods of protecting the individual are equally effective, such as the use of audio-video recording and the right to legal advice (Greer, 1994). Furthermore, the right of access to information during the interrogation stage was a related and important aspect of fair trial (Azzopardi, 2002). According to Pattenden (1995), the right to silence was defined as freedom from self-incrimination and freedom from the silence being used to infer guilt at trial. In principle, it should be implemented both where law enforcers conduct questioning and during trial.

\section{Comparisons of the right to silence in England, China and the United States}

Hong Kong's legal system has been greatly influenced by a history of British colonisation from 1842 to 1997, after which sovereignty reverted to China. An outline of the principles and practices underlying the administration of the right to silence in these two countries is important to understanding the developments in Hong Kong. The fundamental rights conferred in the United States will also be mentioned for purposes of comparison.
In the United States, drawing adverse inferences is proscribed in the Fifth Amendment and brought out in the Miranda $\mathrm{v}$ Arizona case (Klein, 2003). Whereas, in the United Kingdom, the Criminal Justice and Public Order Act 1994 abolished the freedom from adverse inferences being drawn from a person's silence during trial. Curtailing the right to silence would shift the criminal justice system from an adversarial system over to an inquisitorial one (O'Reilly, 1994). The topic is still surrounded by much controversy (Coldrey, 1991; Ingraham, 1996).

In the United Kingdom, the extensive statutory protection concerning the disclosure and flow of information between defence and prosecution during trial is not afforded in the course of interrogation of suspects, a stage of great vulnerability in terms of procedural equity (Toney, 2002). This also applies to Hong Kong, where law enforcers are only required to serve the Cautioned statement on the person during the interrogation stage.

In mainland China, however, the right to remain silent is not afforded to the individual facing criminal charges (Winston, 2003). China made major revisions to the Criminal Procedural Law in 1996 to incorporate the rights of individuals to legal counsel, cross-examination, protection against forced confessions and appeals (Luo, 2000).

$\mathrm{Lu}$ and Miethe (2003) pointed out that an individual may be detained for up to 40 days before being formally charged under Article 69 of the Criminal Procedural Law. This contrasts starkly with the limit of 48 hours' detention in Hong Kong, after which the arrested person should be charged and brought before a magistrate, as specified under section $17 \mathrm{C}(2)$ of the Customs and Excise Service Ordinance, Cap 342.

Furthermore, in China, the privilege against self-incrimination and the presumption of innocence are not clearly defined ${ }^{1}$ 
(Yue \& Chen, 1997). In fact, the Criminal Procedural Law imposes an obligation on suspects to admit guilt, since under Article 93 a suspect must answer the investigator's questions truthfully (Ma, 2003). This in turn instils a sense of justification for law enforcers to use force and torture (Chen \& Song, 2000). The absence of procedural safeguards for the detention and questioning of suspects, restrictions on their access to legal counsel and mitigated sentencing for voluntary confessions, strongly encourage compliance ( $\mathrm{Lu} \&$ Miethe, 2003). In Hong Kong, the entitlement to a reduction of one-third of the sentence upon pleading guilty $^{2}$ serves as a practical incentive to cooperate with the authorities.

An overview of the literature suggests that research on the perspective of the law enforcer is barely sufficient and assumes that law enforcers are passive executors of legal doctrine. In practice, the implementation of legal principles relies on the effectiveness of enforcement. Hence, the conceptual model that law enforcers apply is crucial to evidence collection and its subsequent interpretation.

\section{The right to silence in Hong Kong}

Hong Kong adopted the adversarial system of trial from Britain. The formulation of the Bill in 1997 marked a substantial departure from the Public Order Act in the United Kingdom. Both the common law and Article 11 of the Bill guarantee the right against self-incrimination. The Bill also specified, amongst other rights, that a person should: be presumed innocent until proven guilty; not be compelled to confess guilt; have access to a fair and prompt trial; not be detained in custody whilst awaiting trial; be entitled to free legal assistance and free interpretation services; be treated with humanity and dignity.

The taking of Cautioned statements by law enforcers has been governed by the 'Rules and Directions for the Questioning of Suspects and the Taking of Statements' ('the Rules and Directions') since 1992 (Hong Kong Government, 1992).

Currently, there are seven government organisations involved in criminal law enforcement that are known as the disciplined services ${ }^{4}$ (Chiu, 2006). Each department is responsible for enforcing various statutes, and the nature of the crime and the organisational culture would affect whether and how the Caution was administered.

The taking of Cautioned statements is a crucial step in determining whether there is sufficient evidence prima facie (at first sight) for laying a charge or information against the suspect. In laying a charge, evidence of both actus reus (the guilty act) and mens rea (the guilty conscience) is required. Standardisation of the process of collecting oral evidence conforms to the ideal of equality before the law.

According to Sui (1984), Cautioned statements can be admitted in court as evidence by three pathways. By common law, a confession may be admitted as an exception to hearsay so far as it does not breach the Rules and Directions or is not subsequently excluded in voir dire (preliminary examination) proceedings as being involuntary. They can be admitted as formal admissions under section $65 \mathrm{C}$ of the Criminal Procedure Ordinance, Cap 221 or, where no party objects, within 14 days of service of the copy of the statement, according to section $65 \mathrm{~B}$ of the same Ordinance.

\section{Definition of the Caution and the need for review}

In 1985, the Law Reform Commission ('the Commission') conducted a relatively comprehensive look into the issue of the Caution, confession statements and their admissibility in criminal proceedings. The Commission later published a consultation paper (Law Reform Commission, 1998) and another report (Law Reform Commission, 2000) on statement-taking, focusing 
mainly on streamlining procedures in court.

With specific regard to the right of silence, the definition given by the Commission was that the suspect commits no legal offence by exercising the right unless there were statutory exceptions ${ }^{5}$ (Law Reform Commission, 1985). This is the definition adopted in this study as the normative model for comparison with the mental model of Customs officers.

In addition to the restriction that statutory exceptions impose on the right to silence, the concept of presumptions ${ }^{6}$ (also referred to as negative averment or reverse burden of proof) places the responsibility for proof of innocence on the defendant. Such statutory exceptions and presumptions have the practical effect of incriminating a person who remains silent. This contradicts with the principle stated in the Bill, whereby a person is presumed innocent until proven guilty.

In principle, under Article 39 of the Basic Law (enacted in 1997), the provisions of the International Covenant apply to Hong Kong. Furthermore, Article 160 of the Basic Law states that any contravening laws must be amended or cease to have force. In practice, statutory exceptions and presumptions still exist pending the success of a criminal appeal based on the legality of such laws.

The Commission (Law Reform Commission, 1985) further stated that, in practice, adverse inferences were drawn from a person's silence. These exceptions contradicted the fundamental principle of presumed innocence and protection against self-incrimination. The wordings of the Caution did not reflect this fact.

The 1985 report identified a list of problems in the procedures for statement taking, including the ambiguity of the law regarding the subject, inconsistency in applying procedures, excessive complexity which made relation to real-life situations difficult.
Furthermore, the law excluded evidence that should have been admissible for determining the truth. The list of problems above jeopardised the rights of the individual.

The Commission (Law Reform Commission, 2000) therefore considered the Rules and Directions inappropriate for Hong Kong. There was insufficient protection for the suspect and they consumed a disproportionate amount of resources in determining admissibility. The 2000 report focused mainly on court discretion and procedures, rather than the procedures for the taking of Cautioned statements.

In Britain, the defence succeeded in excluding the confession in 1.5 per cent of cases, whereas in Hong Kong, the figure stood at 25 per cent and possibly as high as 34 per cent (Law Reform Commission, 1985). In the same report, the Commission pointed out that this issue of the admissibility of confessions was detrimental to public confidence in law enforcers and raised doubts as to the occurrence of wrongful acquittals and convictions.

The problem of complexity of the concept has been confirmed in other studies conducted in England and Wales, where only half of police officers demonstrated an understanding of the Caution in its entirety, regardless of seniority, position or length of service (Fenner, Gudjonsson, \& Clare, 2002). The standard practice of asking the suspect 'Do you understand?' was found to be a weak assessment of actual comprehension (Cooke \& Philip, 1998). However, this still remains standard practice in taking statements with the Hong Kong Customs.

The specific problems encountered by law enforcers, as uncovered by the Commission, form the basis of the research question. The problem of understanding the complexity of the mechanism resulted in confusion over the laws and established procedures of interrogation. The Cautioning statement presented difficulties to officers, both in distinguishing the implications of 
the wordings and in the overall redundancy of the process. ${ }^{7}$ Intentional and unintentional non-compliance have a serious impact on the administration of justice. This paper therefore examines the practical issues faced by officers and recommends methods of improvement.

\section{The rights of persons in custody}

The Rules and Directions also make provisions for the rights of persons held in Customs' custody. The crucial concern in the treatment of persons in custody is whether any coercion has been exercised to obtain a therefore inadmissible confession. The facilities available are currently made known to the suspect through the serving of a document known as the "Notice to Persons in Custody' ('the Notice').

The Rules and Directions state that a person under investigation or in custody should be informed of the rights and the facilities available to that person. The most significant deviations between the Notice and the Rules and Directions are on the person's eligibility to comfort, refreshment, interpretation service, the rights of persons under 16 to be accompanied by an adult and to be informed of these rights and facilities available in preparation of a defence.

Article 6 of the Bill states that persons in custody are entitled to the right of being treated with humanity and dignity. The vagueness of these terms is a potential point of legal dispute. The Article also requires the segregation of accused persons from convicted persons and adults from juveniles. There is a practical need to codify the administration of these rights as it would remove ambiguity and ensure that standardised practices are in force across the various law enforcement agencies in Hong Kong as recommended by the Commission's Report on Arrest (Law Reform Commission, 1992).
The passing of the Personal Data (Privacy) Ordinance, Cap 486 ('the Privacy Ordinance') in 1997 further introduced measures to protect the data subject, with exceptions for criminal investigation. According to the first principle, data should only be collected for a lawful purpose and the data subject should be explicitly or implicitly informed of the collection and consequences of non-compliance. This is particularly important where noncompliance would constitute a separate offence, such as the failure of a person under arrest to provide the correct name and evidence of identity under section 17FA of the Customs and Excise Service Ordinance, Cap 342. In order to meet the public's increasing expectations of government transparency and accountability, these principles should be explicitly acknowledged by the suspect.

An important right which is not mentioned in the Notice is the early disclosure of information to the defence, other than a copy of the record of the interview and statement of the offence at the end of the interview. This may hinder the preparation for defence and hence the right to a fair hearing. A person's right to bail and access to free interpretation service is also not found in the Notice. These rights and privileges were laid down with the enactment of the Bill and made imperative the necessity of reviewing the Notice to incorporate these principles.

The requirement of offering consulate or embassy assistance where the suspect is a foreign national is also not included in the Notice. The rights and privileges are laid down in Article 36 of the Vienna Convention on Consular Relations of 24 April 1963 and which specifically applied to Hong Kong under section 3(1) of the Consular Relations Ordinance, Cap 557. This would inadvertently deny the person the opportunity to verify whether he or she is entitled to consular assistance, especially for 
persons with dual nationality who are unaware of the privileges and who only presented one of their nationalities to the officer during interrogation.

The Independent Commission Against Corruption (Treatment of Detained Persons) Order, Cap 204A is a pioneer in the codification of these rights to establish the legal status of the standards of treating persons in detention. A comparison table of the differences and variations of these rights in these documents is presented in Table 1.

In England and Wales, all police interviews with suspects have been required to be audio-taped since 1986 (Zander, 1990). In Hong Kong, the Commission (Law Reform Commission,1985) made recommendations for interviews to be conducted by video-taping. ${ }^{8}$ Although facilities for the audio-visual recording of interrogations exist, the majority of statements taken under caution by Customs are still in physical paper mode. Audio-video recordings were first introduced with the Independent Commission Against Corruption (ICAC) in 1989 and in 1993 with the Police (Law Reform Commission, 2000). Customs implemented audio-video recordings in the taking of Cautioned statements in 1997.

According to Sullivan (2005), the main beneficiaries would be the law officers themselves. However, the practical problems described by the Commission (Law Reform Commission, 2000) above were obstacles to widespread implementation. Sullivan recommends electronic recording to be made compulsory through legislation. In Hong Kong, the right to choose for the interview to be recorded in either video or written form is recognised (Customs and Excise Department, 2005a). However, the availability of such facilities is not communicated through the Notice, which is a formal document administered to the suspect prior to interrogation. Therefore in practice, the application of video-recording would be determined by the officers conducting the interview, rather than being at the discretion of the suspect.

\section{OBJECTIVES AND METHOD OF THE STUDY}

Although the Commission identified problems with the existing Caution, it did not scientifically analyse the conceptual problems faced by law enforcers and how this affected the individual's right to silence. Rather, the Commission's focus was on cost reduction during court trial.

The purpose of the study (conducted between 2005 and 2006) was to look into the administration of the rights of arrested persons under interrogation by Customs law enforcers as compared with the underlying legal principles. It aimed to identify factors affecting the conceptual understanding of Customs law enforcers towards the Caution and to make recommendations for improvement in the practice.

\section{Hypotheses formulation and analysis}

A total of 20 Inspectorate and Customs Officer grade staff was randomly selected from a list of 3,818 personnel of the Service. Of those, four officers were either on leave or occupied by other duties on the scheduled day. An undisguised focused group interview was conducted with these 16 officers. This group is fairly representative of the organisation as officers are posted to a different branch every four years and the average number of branches an officer had worked in was three. ${ }^{9}$ During induction training, officers are also rotated to ensure they receive wide exposure to each branch and undergo a standardised syllabus of training in case processing and law enforcement.

The objective of the focused group interview was to derive the various conceptual levels they had formed of the Caution. Three such conceptual levels 
Table 1: Comparison of information on rights under custody

\begin{tabular}{|c|c|c|c|c|}
\hline Rights & Rules ${ }^{a}$ & Notice $^{b}$ & Procedures $^{c}$ & $204 A^{d}$ \\
\hline Privacy of venue & $\sqrt{ }$ & & & $\begin{array}{l}\sqrt{ } \text { (Detention } \\
\text { Centre) }\end{array}$ \\
\hline Comfort \& refreshment & $\sqrt{ }$ & & & $\begin{array}{l}\sqrt{ } \text { (food, drink, } \\
\text { bed, clothing) }\end{array}$ \\
\hline Toilet \& exercise & & & & \\
\hline Treatment of children \& young persons & $\sqrt{ }$ & & $\sqrt{ }$ & \\
\hline Choice of language & $\sqrt{ }$ & & $\sqrt{ }$ & \\
\hline Supply of written charge & $\sqrt{ }$ & & & \\
\hline To speak on telephone with friends & $\sqrt{ }$ & $\sqrt{ }$ (or relative) & $\sqrt{ }$ & $\begin{array}{l}\sqrt{ } \star \text { (or legal } \\
\text { adviser, or } \\
\text { relative }\end{array}$ \\
\hline Notify a person named by the detainee & & & & $\sqrt{ }$ \\
\hline $\begin{array}{l}\text { For a public officer, notify subject Head of } \\
\text { Department }\end{array}$ & & & & 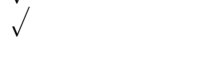 \\
\hline $\begin{array}{l}\text { Communicate privately with a solicitor/ } \\
\text { barrister }\end{array}$ & $\sqrt{ }$ & $\sqrt{ }$ & $\sqrt{ }$ & $\sqrt{ }$ \\
\hline Provided with the Law Society's list of solicitors & $\sqrt{ }$ & $\sqrt{ }$ & $\sqrt{ }$ & \\
\hline $\begin{array}{l}\text { Have a solicitor/barrister present during } \\
\text { investigation }\end{array}$ & $\sqrt{ }$ & $\sqrt{ }$ & $\sqrt{ }$ & \\
\hline $\begin{array}{l}\text { Refuse consulting with a solicitor/barrister } \\
\text { instructed by a third party }\end{array}$ & $\sqrt{ }$ & $\sqrt{ }$ & & \\
\hline Have letters delivered without undue delay & $\sqrt{ }$ & $\sqrt{ }$ & & \\
\hline $\begin{array}{l}\text { Supply a copy of the statement/record of } \\
\text { interview as soon as possible after the interview }\end{array}$ & $\sqrt{ }$ & $\sqrt{ }$ & $\begin{array}{l}\sqrt{ } \text { (or video } \\
\text { tapes) }\end{array}$ & \\
\hline $\begin{array}{l}\text { Where a copy is denied, record the reasons and } \\
\text { cease further interviewing }\end{array}$ & $\sqrt{ }$ & $\sqrt{ }$ & $\sqrt{ }$ & \\
\hline A copy must be supplied upon formal charging & $\sqrt{ }$ & & & \\
\hline Supplied with writing materials & $\sqrt{ }$ & $\sqrt{ }$ & $\sqrt{ }$ & \\
\hline $\begin{array}{l}\text { To be informed of his rights \& facilities } \\
\text { available }\end{array}$ & $\sqrt{ }$ & & & \\
\hline $\begin{array}{l}\text { Cautioned (Rule II) when suspected of } \\
\text { committing an offence }\end{array}$ & $\sqrt{ }$ & & & \\
\hline Cautioned (Rule IIIa) when charged & $\sqrt{ }$ & & & \\
\hline $\begin{array}{l}\text { To write own statement or someone else to } \\
\text { write it }\end{array}$ & $\sqrt{ }$ & & $\sqrt{ }$ & \\
\hline To read or have read to him the statement & $\sqrt{ }$ & & & \\
\hline To make alterations, corrections or additions & $\sqrt{ }$ & & $\sqrt{ }$ & \\
\hline $\begin{array}{l}\text { Substituting a written record by mechanical } \\
\text { recording }\end{array}$ & $\sqrt{ }$ & & $\sqrt{ }$ (choice of) & \\
\hline Detention record to be kept & & & & $\sqrt{ }$ \\
\hline $\begin{array}{l}\text { Personal search before placing in a detention } \\
\text { room }\end{array}$ & & & & $\sqrt{ }$ \\
\hline Responsibilities of the guard & & & & $\sqrt{ }$ \\
\hline Access to medical care & & & & $\sqrt{ }$ \\
\hline Complaints & & & & $\sqrt{ }$ \\
\hline Treatment of female detainees & & & & $\sqrt{ }$ \\
\hline Use of handcuffs & & & & $\sqrt{ }$ \\
\hline Visit by Justices & & & & $\sqrt{ }$ \\
\hline Notice to be displayed & $\sqrt{ }$ & & & $\begin{array}{l}\sqrt{ } \text { (right to ask } \\
\text { for bail) }\end{array}$ \\
\hline
\end{tabular}

Notes:

^ Denotes under Magistrate's order.

${ }^{\text {a }}$ Refers to the Rules and Directions.

${ }^{\mathrm{b}}$ Refers to the Notice to Persons in Custody signed by the suspect.

${ }^{c}$ Refers to the Procedures in Relation to Stop, Search, Arrest and Taking of Statements distributed as leaflets to the public.

${ }^{\mathrm{d}}$ Refers to the ICAC (Treatment of Detained Persons) Order, Cap 204A. 
were identified as the protection against involuntary confessions, the right against self-incrimination and the right against selfincrimination with statutory exceptions. During the focused group interviews, officers were asked how many statements an officer felt were needed in order to feel that they were better experienced and had acquired a level of competence in completing statements without supervision. The answer from respondents was that they required a frequency of around 10 .

Officers were asked what they considered were important factors contributing to their comprehension of the Caution (dependent variable), and based on this, were tabulated with (the independent variables) officer rank (Customs Officers or Inspectorate Officers ${ }^{10}$ ), frequency of experience with taking statements (from none to 10 and more than 10), exposure to statement taking for serious offences ${ }^{11}$ and exposure to further training in criminology. The above aspects were used to assess the knowledge gaps in the officers' concept of the right to silence and to formulate the hypotheses.

A questionnaire based on these levels was successfully conducted on 150 Inspectorate and Customs Officer grade staff randomly selected from the Customs and Excise Service. Of these, 100 were of Customs Officer grade and 50 were from the Inspectorate grade. Civilian staff, Superintendent and Directorate grade officers were not included, as they were not required to administer the Caution. Initially, 200 questionnaires were sent out with a follow-up by telephone to obtain responses. There were 36 non-responses and 14 incomplete questionnaires.

Respondents were asked whether they understood the current Caution. Their selfreported understanding was compared with their ability to explain from recall in their own words the concept of the right of silence. They were also asked to describe, in their own words, what was meant by the concept of presumptions.

Separate chi-square tests were then conducted to test the hypotheses that there was no difference in expected and observed frequencies of the conceptual levels based on officer rank, experience and training in criminology. Respondents were requested to choose one answer they thought best described the Caution. The level of significance (Type I error) was set at 0.05 with 1 degree of freedom.

The first null hypothesis tested officers' conceptual model of the Caution (being against self-incrimination, voluntary confession, self-incrimination with statutory exceptions) for dependence on officer rank:

H01: Officers' concept of the Caution (as being protection against selfincrimination versus voluntary confession) is independent of their rank (Customs Officers versus Inspectorate Officers)

The alternative hypothesis was:

HA: The two criteria of classification are dependent.

As self-incrimination is related to statutory exceptions, only the 67 respondents who mentioned the Caution as being protection against self-incrimination were further asked whether they knew about its effect on the right to remain silent. The data from the first test were thus used to test the second null hypothesis as follows:

H02: Officers' awareness of statutory exceptions is independent of their rank (Customs Officer versus Inspectorate Officers)

The alternative hypothesis was:

HA: The two criteria of classification are dependent. 
Experience was measured on the dimension of the number of interviews an officer had conducted. This formed the third null hypothesis:

H03: Officers' concept of the Caution (as being protection against selfincrimination versus voluntary confession) is independent of their experience (measured in frequency of conducting interviews).

The alternative hypothesis was:

HA: The two criteria of classification are dependent.

Another dimension of experience was by the officers' exposure to interviewing for serious crimes. This was the basis of the fourth null hypothesis:

H04: Officers' concept of the Caution (as being protection against selfincrimination versus voluntary confession) is independent of their experience in interrogation of serious offences.

The alternative hypothesis was:

HA: The two criteria of classification are dependent.

Officers who pursued further training in criminology were further measured as a subset. Only a total of 27 officers out of 150 had received further training in a discipline related to criminology. The results from this analysis would reveal whether experience and training had an effect on the learning curve of officers regarding knowledge of the right to silence relative to the Caution. This was tested in the fifth and last null hypothesis, as follows:

H05: Officers' concept of the Caution (as being protection against self- incrimination versus voluntary confession) is independent of their exposure to further training in criminology.

The alternative hypothesis was:

HA: The two criteria of classification are dependent.

Apart from the chi-square tests, officers were asked what effect the Caution had on obtaining confessions and cooperation from the suspects where suspects chose to exercise the right to remain silent. Officers were also asked what the main objective was in taking statements. They were also asked for an explanation of the effect of presumptions and statutory exceptions. Officers were asked about their perception of their training received on Cautioned statements and the source of knowledge. Finally, officers were asked whether they could distinguish two Cautions.

\section{RESULTS}

\section{Concept of the Caution by officer rank}

Although all officers reported that they understood the current Cautioning statement, when they were asked to explain what was meant by the Caution in their own words, only 45 per cent were able to point out the right to silence as the privilege against self-incrimination (see Table 2). Of these, only 25 per cent were able to point out the relevance of statutory exceptions and their effect on the Caution (see Table 3). The remaining proportion explained the Caution in literal terms as being proof that the person giving oral testimony did so without coercion and voluntarily, ie the interpretation of 'you are not obliged to say anything'.

The results can be found in the two-bytwo table below: 
Table 2: Conceptual model of the caution by officer rank

\begin{tabular}{lllr}
\hline Officer rank & \multicolumn{2}{c}{ Concept of the caution } & \\
\cline { 2 - 3 } & $\begin{array}{l}\text { Self- } \\
\text { incrimination }\end{array}$ & $\begin{array}{l}\text { Voluntary } \\
\text { confession }\end{array}$ & \\
& $38(44.67)$ & $62(55.33)$ & 100 \\
Rank and File & $29(22.33)$ & $21(27.67)$ & 50 \\
$\begin{array}{l}\text { Inspectorate } \\
\text { Total }\end{array}$ & 67 & 83 & 150 \\
\hline
\end{tabular}

Note:

Figures in brackets denote expected frequencies. There were 3,818 officers in the agency at the time the questionnaire was conducted.

For hypothesis one, the data calculate as $\chi^{2}(1, N=150)=5.4, p=0.02$. As the $p$-value is well below 0.05 , it can be concluded that there is a significant difference between front-line and supervisory officers' concept of the Caution when compared with the expected frequency based on the pooled distribution. Supervisory officers explained the Caution as being concerned with the right against self-incrimination more than with voluntary confession.

Officers whose concept of the Caution was that it represented voluntary confession, explained the Caution word for word. The phrase 'you are not obliged to say anything ...' conveyed the meaning that whatever a suspect says thereafter would be made by free will and not as being under an obligation to comply with the request of the officer. Officers holding this concept were more likely to be from the front-line grade. As they are responsible for conducting the bulk of all records of interviews and due to the ambiguity of the wordings, the results indicate that the majority of suspects had given oral evidence without a sufficient explanation of their rights and privileges as to the purpose and consequences of remaining silent.

Distinctive of the bilingual environment in which the law operates in Hong Kong, as practised, English-speaking suspects are usually interviewed by Inspectors. They are more proficient in the language due to higher academic requirements for recruitment into that rank. ${ }^{12}$ From the results of this study, Inspectors were also more capable of explaining the meaning of the Caution to the suspect. Since both Chinese and English are the official languages of Hong Kong and the majority of suspects speak Chinese, this practice places suspects who provide evidence in Chinese at a disadvantage in terms of access to an accurate explanation of the Caution from the officer taking the statement.

It may be argued that where a suspect is in doubt concerning these rights, a query could be raised at any time with the officer and this request could be relayed to the Inspector in charge of the case. However, suspects may wrongly perceive that they understand the Caution through familiarity with the phrase and therefore would be unable to raise queries on an issue that they do not adequately comprehend.

For hypothesis two, the results can be found in the two-by-two table below:

Table 3: Awareness of statutory exceptions by officer rank

\begin{tabular}{llll}
\hline Officer rank & \multicolumn{2}{c}{ Concept of the caution } & \\
\cline { 2 - 3 } & $\begin{array}{l}\text { Statutory } \\
\text { exceptions }\end{array}$ & $\begin{array}{l}\text { Self- } \\
\text { incrimination }\end{array}$ & \\
\hline Rank and File & $6(9.64)$ & $32(28.36)$ & 38 \\
Inspectorate & $11(7.36)$ & $18(21.64)$ & 29 \\
Total & 17 & 50 & 67 \\
\hline
\end{tabular}

At $p=0.04$, the $\chi^{2}(1, N=67)=4.26$ was significant. Therefore, it is concluded that significantly more supervisory officers conceptualised the Caution as being affected by statutory exceptions. 
Officers who could point out the effect of statutory exceptions to the Caution found its application potentially misleading to the person being interviewed, as silence in these cases would inevitably lead to incrimination. A defence raised by the suspect in the course of being interviewed would only serve as a matter of mitigation for the court to decide.

Although the standard Caution was administered and the suspect was invited either to sign or express understanding, it was felt that the wording of the Caution did not fully reflect the effect of answering or refusing to answer questions or give oral evidence. The reason that officers administered the Caution was based on the requirement of the Rules and Directions and the absence of further directives.

The prosecution case is summarised in the charge sheet and submitted to the magistrate. Where the defendant pleads guilty to the charge, the contents of the record of interview would not be further scrutinised. The contents of the record of interview would only be put before the magistrate or judge upon a not-guilty plea. This procedure was detrimental to the defendant's interests as there was a potential for false incrimination. From the defendant's position, since the charge proceeded despite a defence being made during the interview, this would impart the impression that the contents of the interview had already been considered in its entirety. The process is conducive of convictions at the expense of fairness to the defendant.

\section{Concept of the Caution by officers' experience and training}

For the third hypothesis, which measured the effect of experience as the number of interviews an officer had conducted on the conceptualisation of the Caution, the results are depicted in the two-by-two table below:
Table 4: Experience in interrogation and concept of the caution

\begin{tabular}{|c|c|c|c|}
\hline & \multicolumn{2}{|c|}{ Concept of the caution } & \multirow[b]{2}{*}{ Total } \\
\hline & $\begin{array}{l}\text { Self- } \\
\text { incrimination }\end{array}$ & $\begin{array}{l}\text { Voluntary } \\
\text { submission }\end{array}$ & \\
\hline 0 to 10 & $39(41.54)$ & $54(51.46)$ & 93 \\
\hline Over 10 & $28(25.46)$ & $29(31.54)$ & 57 \\
\hline Total & 67 & 83 & 150 \\
\hline
\end{tabular}

The $\chi^{2}(1, N=150)=0.74, p=0.39$. As this was below the critical value, it can be concluded that the experience of an officer as quantified by the number of records of interview taken, had little effect on awareness of the right against selfincrimination. ${ }^{13}$

For the fourth hypothesis, which tested officers' concept of the Caution based on exposure to statement taking for serious crimes, the results are tabulated in the twoby-two table below:

Table 5: Experience in interrogation of serious crimes and concept of the caution

\begin{tabular}{lllr}
\hline & \multicolumn{2}{l}{ Concept of the caution } & \\
\cline { 2 - 3 } & $\begin{array}{l}\text { Self- } \\
\text { incrimination }\end{array}$ & $\begin{array}{l}\text { Voluntary } \\
\text { submission }\end{array}$ & Total \\
\hline Ordinary offences & $42(47.79)$ & $64(59.21)$ & 107 \\
Serious offences & $24(19.21)$ & $19(23.79)$ & 43 \\
Total & 67 & 83 & 150 \\
\hline
\end{tabular}

The $\chi^{2}(1, N=150)=6.72, p=0.01$. As this exceeds the critical value, it can be said that experience in taking records of interviews with suspects of serious arrestable offences significantly affected the officers' concept of the right to silence. This is 
probably due to a heightened awareness of the importance of the application of negative averment to prosecution for serious offences, chances and implications of the suspect remaining silent, the prospect of dealing with the defence counsel and greater adverse consequences of making a mistake on their own reputation. Officers handling serious offences would be inclined to be more involved in the process of taking the record of interview. Their source of knowledge was usually from exposure to specialised training in statement taking and sharing of experience from previous court judgments.

The fifth and final hypothesis tested whether exposure to further training in criminology significantly affected their understanding of the Caution, with the results shown in the two-by-two table below:

Table 6: Further training in criminology and concept of the caution

\begin{tabular}{lcl}
\hline & $\begin{array}{c}\text { Observed } \\
\text { frequency }\end{array}$ & $\begin{array}{l}\text { Expected } \\
\text { frequency }\end{array}$ \\
\hline $\begin{array}{l}\text { Voluntary submission } \\
\text { Self-incrimination }\end{array}$ & 7 & 14.94 \\
Total & 20 & 12.06 \\
\hline
\end{tabular}

The $\chi^{2}(1, N=150)=9.45, p=0.002$. As this exceeds the critical value, it can be said that further training in criminology significantly affected the subject's concept of the right to silence. Exposure to the principle of the right to silence relative to the Caution is therefore the most important factor of those considered in this study to increasing officers' comprehension.

A majority of officers were of the opinion that the principle of the right to silence made it more difficult to obtain a confession from suspects who were familiar with these immunities. However, they reported that over 95 per cent of persons to whom they administered the Caution chose to answer the questions given to them and were cooperative. Of those who remained silent, 80 per cent were suspects facing the possibility of incarceration for a serious offence.

A clear majority of officers (76 per cent) regarded the purpose of taking statements as being to obtain incriminating evidence. These perspectives would potentially cause the officer to pose questions that tended to incriminate the person rather than as a factfinding exercise. The remaining percentage of officers was of a more neutral view that interrogation provided suspects with an opportunity to make an exculpatory statement as an alternative to selfincrimination.

When asked independent of the Caution statement whether they understood the effect of presumptions and statutory exceptions requiring the provision of information, officers unanimously reported understanding of the concept with some giving specific reference to the Dangerous Drugs Ordinance and licensing offences. They were able to explain the concept in their own words as placing the burden of proof on the shoulders of the suspect. This finding reveals a gap between officers' reported understanding of the theory underlying interrogation and its practical application.

When asked the source of their knowledge, officers associated it with induction training. However, for the taking of Cautioned statements, all officers described the training as vocational. The main focus of statement-taking courses was on the procedures of administering the Caution. When officers were asked what distinguished Rule II from Rule III(a), all of them replied that the former was applied to suspects and the latter for laying a charge. They could not understand the principle 
behind differences in wording between the two.

\section{CONCLUSION AND DISCUSSION}

The results of this interview indicate that there is a gap between the practice and conceptual understanding of legal theories underlying the taking of Cautioned statements. The findings confirm that there is a substantial amount of controversy over what the Caution actually represents. A majority of officers defined the Caution literally as proof of voluntary admission, while the remainder perceived the Caution as a communication of the rights against selfincrimination. Factors contributing to the situation are complexity of the underlying legal principles, ambiguity in the wordings of the Caution and the variety of interpretations that could be implied during trial in a not-guilty plea.

Although the Basic Law of Hong Kong makes provisions for the application of the International Covenant, existing laws and enforcement practices are still in place and these require review in order for the provision actually to become effective. The laws on statutory exceptions and presumptions reverse the presumption of innocence and the right of a person not to be compelled to give self-incriminating testimony or to confess. The effect of these laws is not fully reflected in the wordings of the Caution. Under the International Covenant, an individual has the right to provision of adequate time and facilities for the preparation of a defence, however, during the stage of interrogation, procedures on the disclosure of information are not clearly defined. Therefore, actual practice has the effect of limiting a person's access to these rights.

In order to protect the rights of an individual, the Caution should include words that expressly refer to the right against self-incrimination. This concept is a fundamental right ensured under the Bill.
Where statutory exemptions limit this right or place the burden of proof on the suspect, additional words should be added to the Caution to communicate the fact, eg wordings such as 'You are required by law to provide information regarding ... and failing to do so is an offence'.

Codification of the Caution and its administration would ensure the admissibility of the evidence in court, standardisation across law enforcement agencies and a reduction in the occurrence of voir dire proceedings. The Caution should be administered with an explanation of how the answers will be used and processed, such as when the terms of the Caution will be considered once charges have been laid (after a not-guilty plea).

The suspect should be notified that the contents of the record of interview would be taken as truth and subject to scrutiny for perjury. As mentioned earlier, the suspect is asked to sign a Rule IV(e) certification at the end of the statement. It is recommended to place wordings such as 'The statement I am about to make is true and I understand that I may be prosecuted for making a false statement', at the start of the interview. Whilst it is not be an offence to remain silent, it is an offence to provide false information.

Audio-video recording of all records of interview should be made mandatory and directly admissible as evidence, in order to prevent allegations of coercion against officers and to protect the suspect. The use of mechanical means would ensure the accuracy and completeness of the record.

Recruitment of officers of higher academic standing into the Customs Officer grade would be beneficial to the administration of law enforcement. Officers should also be exposed more thoroughly to the theoretical implications of the right to silence during induction training. Procedural guidelines should also be issued to ensure that officers explain these rights to a 
suspect without perverting the course of justice. Emphasis should be placed on theoretical training rather than reliance on individual officer experience, in order to raise the standards of interrogation. Standing orders and circulars should be revised to incorporate a revised notification to inform the suspect of the rights and facilities available.

The results of this research indicate that rigid compliance by officers with the Rules and Directions in the absence of subsequent directives places the suspect in jeopardy. The Rules and Directions are not sufficient to ensure the suspect is fully informed of the effect of remaining silent. This is particularly so in situations where statutory exceptions and negative averment have an effect on individual rights and freedoms.

A revision should be made to the 1992 Rules and Directions to incorporate the principles subsequently introduced through the Bill and the Privacy Ordinance. These guidelines on administering the rights of a person in custody should have the force of law. This will reduce the chance of misinterpretation and has the twofold benefit of guarding against malpractice on the one hand and further protecting the suspect's rights on the other hand. The method of considering and making use of the contents of the record of interview should also be made known to the suspect, such as the effects of pleading and not pleading guilty.

In terms of disclosure of materials to the defence, the suspect should be served with all the prosecution documents, since this is crucial for the preparation of a defence. In order to ensure that relevant legal defences are duly considered, any statements that contribute to proof of the innocence of the defendant should also be included.

\section{Limitations}

Some of the limitations of the research are that the scale covers only a limited number of independent variables. There may be other factors affecting the conceptualisation of the Caution. Officers' concept of the Caution may not fully reflect the actual practice of administering the interview. Operational factors such as cultural norms, peer and supervisory pressure, and the complex interaction between suspect and interviewer are also anticipated to affect the outcome of the interview.

This research focuses on the administration of the Caution, rather than focusing on reasons for the suspect's behaviour. Confessions could have been made due to the lack of awareness of the far-reaching consequences of giving self-incriminating testimony, an overestimation of selfcomprehension, psychological factors such as coincidental remorse of the suspect, socio-economic factors such as the lack of resources in terms of time, money and knowledge, and duress and over-reliance on the judicial process to represent the suspect's interests.

The size of the sample of 150 officers is comparatively small. However, given that the Customs and Excise Department has 3,818 disciplined service members (Customs and Excise Department, 2005b) and homogeneity of social, educational, ethnic and cultural background of officers, the findings are fairly representative.

\section{Notes}

1. Although China became a signatory of the United Nations International Covenant on Civil and Political Rights in 1998 ('the International Covenant'), the National People's Congress has yet to incorporate these protections into the legislation (Yue, 2003). Article 14(3) $(\mathrm{g})$ of the International Covenant laid down the right of a person not to be compelled to testify against himself or to confess guilt (McGoldrick, 1991). China is neither party to the constitution of the International Criminal 
Court nor is she a state party to the Rome Statute (Findlay, 2007).

2. Reduction of sentence for guilty pleas is mentioned in HKSAR v Lee Takkwan [1997] Cr App 177. Furthermore, the sentence can be reduced based on consideration of other additional factors, such as the assistance and cooperation of the convicted person with the authorities, as mentioned in AttorneyGeneral v Ching Kwok-hung [1990] Cr App 15.

3. The Rules and Directions were used as a balance between the need to codify the Caution and the need to ensure admissibility of oral or written confessions as evidence in the law courts. Fair administration of the interrogation process is also essential to protecting both the rights of the suspect and the law enforcer in disputes over malpractice and coerced confessions.

The Rules and Directions were published in the Government Gazette back in 1992 and superseded the previous guidelines laid down by the Judges' Rules of 1912. The Rules and Directions contained the wordings of the Caution and guidelines on the method of administration. The effect of the Rules and Directions was not made legally binding, and non-compliance did not necessarily invalidate the charge or the admissibility of the statement (Heilbronn, 1995; Law Reform Commission, 2000).

Although the Rules and Directions only specifically mention Customs as a law enforcement agency subject to these guidelines, in addition to the Hong Kong Police, Immigration Department and the Independent Commission Against Corruption (ICAC), these establishments are only a subset of all the government agencies responsible for enforcing criminal law. The Rules and Directions actually mentioned that the guidelines should be followed as far as practicable by officers charged with the duty of investigating offences or charging offenders.

4. These are the Police Force, Immigration, Correctional Services, Fire Services, Customs and Excise Service, the Independent Commission Against Corruption and the Government Flying Service.

5. Examples of such statutory exceptions can be found in the Organised and Serious Crimes Ordinance, Cap 455, s. 3(11). This section specifically mentions that a person is not excused from providing information or material even where doing so would incriminate that person. Under the Drug Trafficking (Recovery of Proceeds) Ordinance, Cap 405, s. 25A, a person is required to disclose knowledge or suspicion that property represents the proceeds of drug trafficking to any member of the Customs and Excise Service. A person entering or leaving Hong Kong is required to furnish information of cargo to a member of Customs of or above the rank of Inspector, in accordance with the Import and Export Ordinance, Cap 60, s. 15(1)(a). Another example of statutory obligations to provide information can be found in the Dutiable Commodities Ordinance, Cap 109, s. 34A, where a person is required to make a declaration on the quantity of dutiable goods carried by such person. When arrested, a person is also required to give his or her correct name or produce evidence of identity, as specified under the Customs and Excise Service Ordinance, Cap 342, s. 17FA.

6. An example of a presumption can be found in the Dangerous Drugs Ordinance, Cap 134, s. 47(2), which presumes that a person in possession of a drug has knowledge of the nature of 
the drug until the contrary is proven. A similar clause can be found in the Control of Chemicals Ordinance, Cap 145, s. 10 .

7. The rule II Caution (Hong Kong Government, 1992), administered to a person suspected of having committed a criminal offence reads as follows:

You are not obliged to say anything unless you wish to do so, but what you say may be put into writing and given in evidence.

The rule III(a) Caution (Hong Kong Government, 1992) is administered at the point where sufficient evidence is acquired to establish a prima facie case and prior to laying charges against the person. It reads as follows:

Do you wish to say anything? You are not obliged to say anything unless you wish to do so but whatever you say will be taken down in writing and may be given in evidence.

Rule IV(e) (Hong Kong Government, 1992) states that a certification must be made at the end of the statement. The certification reads as follows:

I have read the above statement and I have been told that I can correct, alter or add anything I wish. This statement is true. I have made it of my own free will.

The Caution is therefore quite a redundant process, with two quite indistinguishable Cautions (Rule II and Rule III(a)) appearing in the same record of interview. Rule II is used at the start of statement taking and Rule III(a) where a charge will be laid. The only difference in wording is that Rule
II states that what the suspect says 'may' be put into writing, whereas, for Rule III(a), 'whatever' the suspect says will be taken down in writing. In reality, this would hardly be applicable and therefore the distinction in wording loses practical relevance.

8. The benefits of using audio-visual records are to establish that the suspect made the statement voluntarily. The practical difficulty in using audio-visual recordings was the need to prepare a full transcript of what was said during the interview (Law Reform Commission, 2000). Making the media on which a record of interview is taken directly admissible would be one alternative to overcome this barrier. This would potentially shift the workload to the courts.

9. The three Branches are the Boundary and Ports Branch, the Administration and Excise Branch and the Intelligence and Investigation Branch.

10. Rank and file officers are front-line staff whereas Inspectorate grade officers are supervisory staff.

11. Serious crimes are defined in this study as equivalent to a 'serious arrestable offence under the Dangerous Drugs Ordinance, Cap 134, for which a sentence of seven or more years may be imposed.

12. The minimal entry requirements for Inspectorate Officers were attainment of a pass in two subjects at Hong Kong Advanced Level and three subjects at Grade C in the Hong Kong Certificate of Education Examination (see http:// www.customs.gov.hk/eng/notice_recr uit_insp_e.html). Should these not include Chinese and English, then a Grade E at Certificate level is required. For Customs Officers, the requirement is Grade $\mathrm{E}$ in three subjects at Certificate level (see http://www.customs. gov.hk/eng/notice_recruit_co_e.html). 
13. The results suggest that it is possible to conduct the record of interview separately from the knowledge of the implications of the Caution. The Caution becomes a formality, with fundamental rights seldom exercised fully in the interests of the suspect.

\section{References}

Azzopardi, J. H. (2002, April). Disclosure at the police station, the right of silence and DPP v. ARA. Criminal Law Review, 295-300.

Berger, M. (1995). Of policy, politics, and parliament: The legislative rewriting of the British Right to Silence. American Journal of Criminal Law, 22, 391-438.

Chen, G. Z., \& Song, Y. H. (2000). Research on the issues in implementation of the Criminal Procedure Law. Beijing: China Legal System Publishing House.

Chiu, W. K. (2006). Law enforcement and the disciplined services in Hong Kong. Hong Kong: Sun Light Printing.

Cooke, D., \& Philip, L. (1998). Comprehending the Scottish Caution: do offenders understand their right to remain silent? Legal and Criminological Psychology, 3, 13-27.

Coldrey, J. (1991). The right to silence: should it be curtailed or abolished? Anglo-American Law Review, 20(1), 51-62.

Customs \& Excise Department. (2005a). Procedures in Relation to Stop, Search, Arrest and Taking of Statement (Brochure). Hong Kong: Author.

Customs and Excise Department. (2005b). Hong Kong: The facts, Customs and Excise. Retrieved 12 February, 2006, from http:// www.info.gov.hk/hkfacts/customex.pdf.

Fenner, S., Gudjonsson, G. H., \& Clare, I. C. H. (2002). Understanding of the current police caution (England and Wales) among suspects in police detention. Journal of Community \& Applied Social Psychology, 12(2), 83-93.

Findlay, M. (2007). China's place in international criminal justice. In Conference Organising Committee (Ed.), Crime, Law and Justice in Chinese Societies: Global Challenges and Local Responses: Legal Reform 1 (pp. 55-56). Chinese University of Hong Kong: School of Law and Department of Sociology.

Greer, S. (1994). The right to silence, defence disclosure, and confession evidence. Journal of the Law Society, 21(1), 102-118.

Heilbronn, G.. N. (1995). Criminal Procedure in Hong Kong (pp. 16, 17, 27-33) (3rd ed.).

Longman: Hong Kong.

Hong Kong Government. (1992). Hong Kong Government Gazette 1992, Special Supplement Number 5.

Ingraham, B. L. (1996). The right of silence, the presumption of innocence, the burden of proof, and a modest proposal: A reply to O'Reilly. Journal of Criminal Law and Criminology, 86(2), 559-595.

Klein, S. R. (2003). No time for silence. Texas Law Review, 81(5), 1337-1360.

Law Reform Commission. (1985). Confession statements and their admissibility in criminal proceedings: Topic 8 . Hong Kong: Hong Kong Government.

Law Reform Commission. (1992). Report on arrest: Topic 25. Hong Kong: Hong Kong Government.

Law Reform Commission. (1998). Consultation paper on the procedure governing the admissibility of confession statements in criminal proceedings. Hong Kong: Hong Kong Government.

Law Reform Commission. (2000). Report on the procedure governing the admissibility of confession statements in criminal proceedings. Hong Kong: Hong Kong Government.

Leo, R. A. (1996). Inside the interrogation room. Journal of Criminal Law and Criminology, 86(2), 266-303.

Lu, H., \& Miethe, T. D. (2003). Confessions and criminal case disposition in China. Law E Society Review, 37(3), 549-578.

Luo, W. (2000). The amended Criminal Procedural Law and the Criminal Court Rules of the People's Republic of China. Buffalo, NY: William S. Hein \& Co., Inc.

Ma, Y. (2003). The powers of the police and the rights of suspects under the amended Criminal Procedure Law of China. Policing: 
An International Journal of Police Strategies \& Management, 26(3), 490-510.

McGoldrick, D. (1991). The Human Rights Committee, its role in the development of the International Covenant on Civil and Political Rights. Oxford: Clarendon Press.

O'Reilly, G. W. (1994). England limits the right to silence and moves towards an inquisitorial system of justice. Journal of Criminal Law and Criminology, 85(2), 402-452.

Pattenden, R. (1995, August). Inferences from silence. Criminal Law Review, pp. 602-611.

Sui, S. C. (1984). The criminal law in Hong Kong. Hong Kong: Rabrodent. (Please contact the author for further details.)

Sullivan, T. P. (2005). Electronic recording of custodial interrogations: Everybody wins. Journal of Criminal Law and Criminology, 95(3), 1127-1144.
Toney, R. J. (2002). English criminal procedure under Article 6 of the European Convention on Human Rights: Implications for custodial interrogation practices. Houston Journal of International Law, 24, 411-474.

Winston, K. (2003). On the ethics of exporting ethics: The right to silence in Japan and the US. Criminal Justice Ethics, 22(1), 3-20.

Yue, L. L., \& Chen, R. H. (1997). International standards on criminal justice and the amended Criminal Procedure Law. Tribune of Political Science and Law, 3, 44-56.

Yue (2003) The powers of the police and the rights of suspects under the amended Criminal Procedure Law of China. Policing, 26(3), 490-510.

Zander, M. (1990). The Police and Criminal Evidence Act. London: Sweet and Maxwell. 